\title{
Antibody Markers Identify a Common Progenitor to Sympathetic Neurons and Chromaffin Cells in vivo and Reveal the Timing of Commitment to Neuronal Differentiation in the Sympathoadrenal Lineage
}

\author{
David J. Anderson, ${ }^{1}$ Josette F. Carnahan,, ${ }^{2, a}$ Arie Michelsohn, ${ }^{2}$ and Paul H. Patterson ${ }^{2}$ \\ 'Howard Hughes Medical Institute and '2Division of Biology, California Institute of Technology, Pasadena, California 91125
}

Using specific antibody markers and double-label immunofluorescence microscopy, we have followed the fate of progenitor cells in the sympathoadrenal (SA) sublineage of the neural crest in developing rat embryos. Such progenitors are first recognizable in the primordial sympathetic ganglia at embryonic day 11.5 (E11.5), when they express tyrosine hydroxylase. At this stage, the progenitors also coexpress neuronal markers such as SCG10 and neurofilament, together with a series of chromaffin cell markers called SA15 (Carnhan and Patterson, 1991a). The observation of such doubly labeled cells is consistent with the hypothesis that these cells represent a common progenitor to sympathetic neurons and adrenal chromatfin cells. Subsequent to E11.5, expression of the chromaffin markers is extinguished in the sympathetic ganglia but retained by cells within the adrenal gland. Concomitant with the loss of the SA1-5 immunoreactivity in sympathetic ganglia, a later sympathetic neuron-specific marker, B2, appears. In dissociated cell suspensions, some B2 ${ }^{+}$cells that coexpress SA1 are seen. This implies a switch in the antigenic phenotype of developing sympathetic neurons, rather than a replacement of one cell population by another. The SA1 $\rightarrow$ B2 transition does not occur for the majority of cells within the adrenal primordium. In vitro, most $\mathrm{B2}^{+}$cells fail to differentiate into chromaffin cells in response to glucocorticoid. Instead, they continue to extend neurites and then die. Taken together, these data imply that the SA1 $\rightarrow B 2$ transition correlates with a loss of competence to respond to an inducer of chromaffin differentiation. Thus, the development of SA derivatives is controlled both by environmental signals and by changes in the ability of differentiating cells to respond to such signals.

\footnotetext{
Received Jan. 25, 1991; revised May 1, 1991; accepted June 11, 1991.

We are grateful to Joan Roach for assistance with histology and immunofluorescence, to Shelly Diamond for help with cell sorting, and to Li-Ching Lo for the preparation of anti-SCG10 antibodies. We also thank Dr. Jane Dodd (Columbia University, New York) for the generous gift of monoclonal antibody B2 and for helpful suggestions. We thank members of the Anderson laboratory for helpful discussions. This work was supported by NIH Grant NS23476 to D.J.A., and an NINDS grant (Javits Neuroscience Investigator Award) and a McKnight Foundation Neuroscience Research Project Award to P.H.P. D.J.A. is an Assistant Investigator of the Howard Hughes Medical Institute.

Correspondence should be addressed to David J. Anderson, Division of Biology, 216-76, California Institute of Technology, Pasadena, CA 91125.

a Present address: AMGEN, Inc., Amgen Center, Thousand Oaks, CA 91320 1789.

Copyright (c) 1991 Society for Neuroscience $0270-6474 / 91 / 113507-13 \$ 05.00 / 0$
}

An important problem in developmental neurobiology concerns the mechanism of diversification of the cell types that derive from the neural crest (Le Douarin, 1982). The dissection of this process has been aided by the use of monoclonal antibodies, which have proven useful tools for the study of neural development (Mirsky, 1982; Reichardt, 1984). Such antibodies can provide molecular markers of differentiation and can reveal important differences between cells that are otherwise indistinguishable. The preceding article (Carnahan and Patterson, 1991a) describes the generation and characterization of a novel set of monoclonal antibodies (SA1-5) that, in the postnatal rat, specifically label adrenal chromaffin cells, the major endocrine derivative of the neural crest. These antibodies provide a set of reagents that can be used to identify chromaffin cells and their precursors in developing embryos.

Studies of postnatal (Unsickcr ct al., 1978; Doupe et al., 1985a,b) and of embryonic chromaffin cells (Anderson and Axel, 1986; Seidl and Unsicker, 1989a,b) have suggested that these adrenal medullary cells derive from a progenitor whose alternate fate is to become a sympathetic neuron. However, it has been difficult to establish whether this lineage relationship holds in vivo. To address this issue, we have examined in sections of developing rat embryos the pattern of expression of the chromaffin-specific sympathoadrenal (SA) antigens in relationship to that of neuron-specific markers. Neuronal markers in this lineage include intracellular proteins such as neurofilament 68 $\mathrm{kDa}$ (NF68) (Cochard and Paulin, 1984) and SCG10 (Anderson and Axel, 1985; Stein et al., 1988b), as well as cell surface antigens such as B2 (Anderson and Axel, 1986; Anderson, 1988). Because several of these markers are sequentially expressed in an overlapping manner, the developmental segregation of sympathetic neurons and chromaffin cclls from their precursor(s) can be traced in situ.

We found that $\mathrm{SA}^{+}$cells within the sympathetic ganglion primordium initially coexpress SCG 10 and tyrosine hydroxylase (TH), suggesting that they have the potential to become either sympathetic neurons or chromaffin cells. Subsequently, SA1 immunoreactivity is lost and B2 immunoreactivity appears in these sympathetic neuroblasts. By contrast, this antigenic switch does not occur for most of the developing adrenal medullary population. Experiments in vitro suggest that the $\mathrm{SA} 1 \rightarrow \mathrm{B} 2$ switch correlates with a loss of competence to respond to glucocorticoids, and commitment to the neuronal pathway of differentiation. 


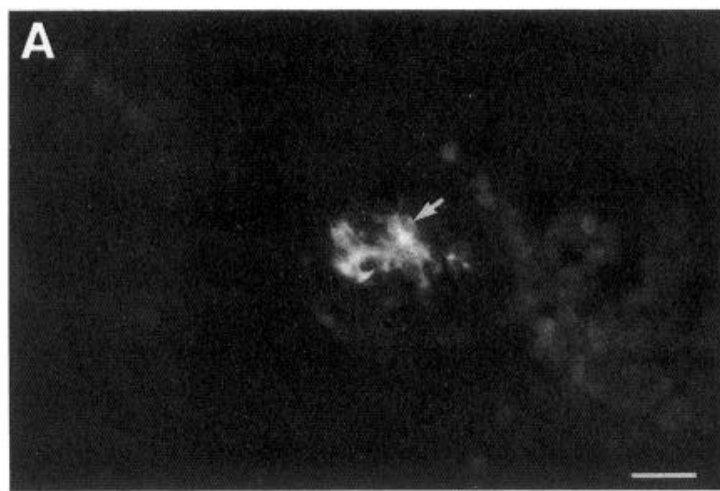

SA-1

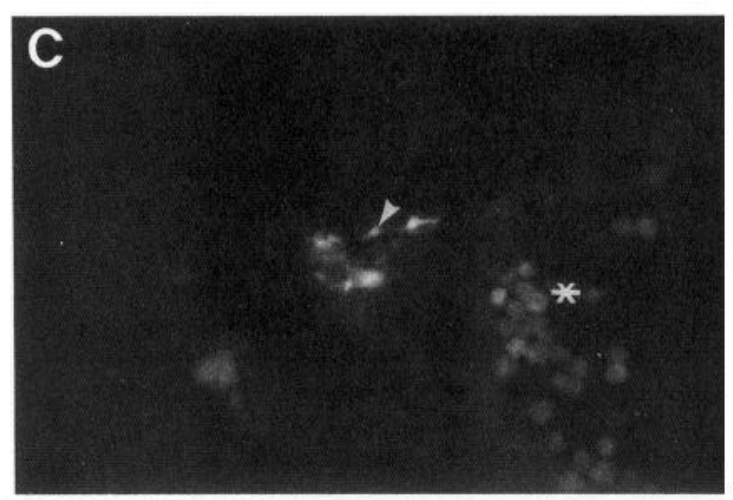

SA-1

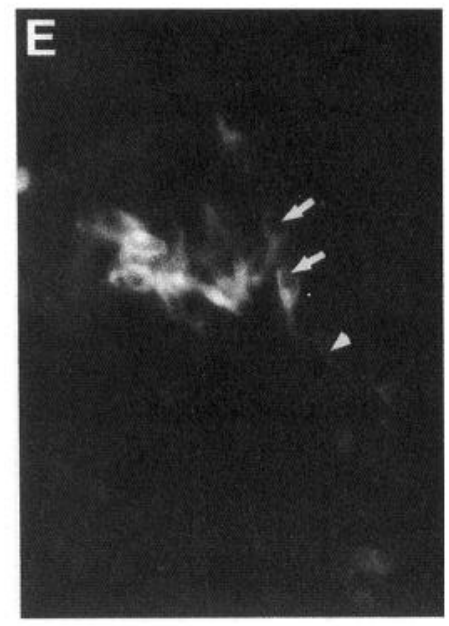

SA-1

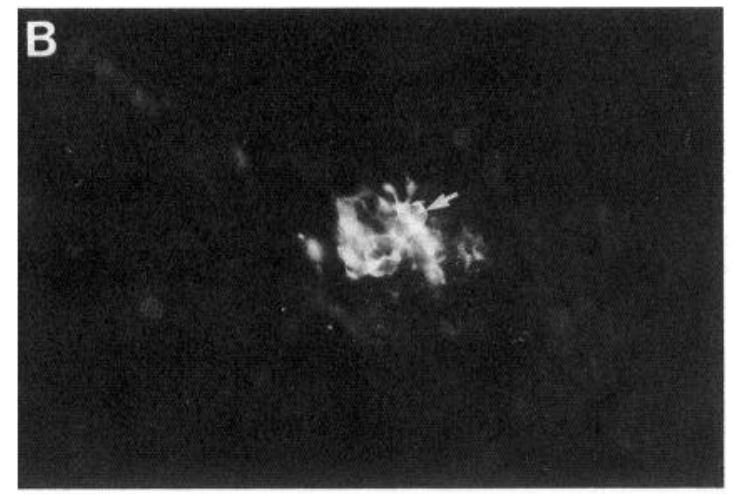

$\mathrm{TH}$

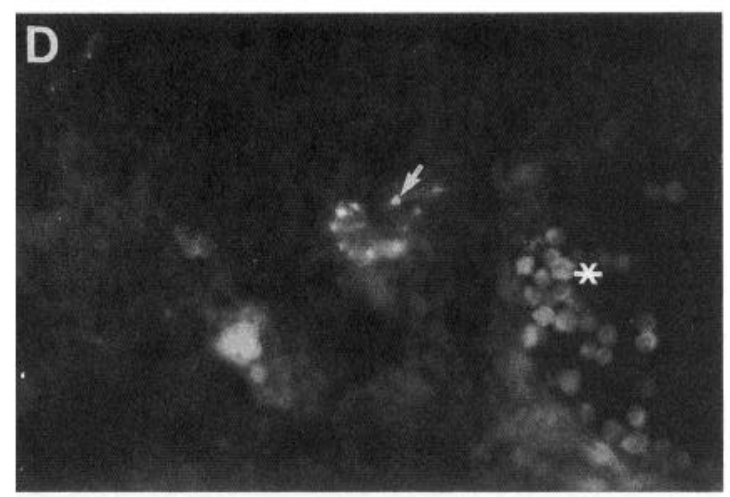

SCG10

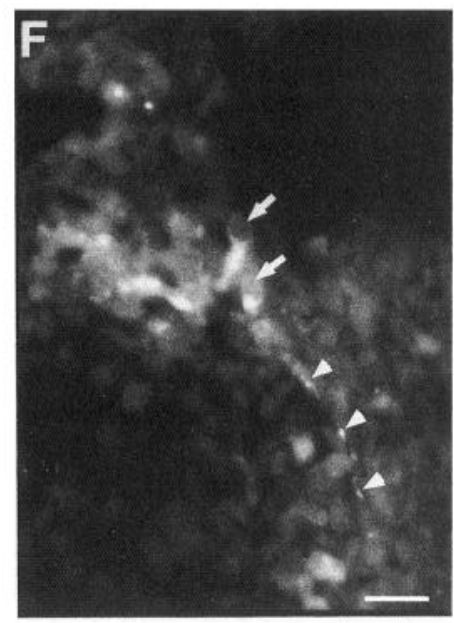

SCG10

Figure 1. Initial expression of SAl occurs in developing sympathetic ganglia. Sections are through sympathetic ganglion primordia, at E11.5. The same section was doubly labeled with SA1 $(A)$ and TH $(B)$. The same section was doubly labeled with SA1 $(C)$ and polyclonal anti-SCG10 $(D)$. Arrows indicate individual doubly labeled cells. $E$ and $F$, Higher-magnification view illustrating two process-bearing cell bodies (arrows) doubly labeled by SA1 $(E)$ and SCG10 $(F)$. Arrowheads indicate the process from one cell, which is also doubly labeled. Asterisk in $C$ and $D$ indicates autofluorescent blood cells in the dorsal aorta. The specific staining patterns illustrated were not observed in controls lacking primary antibody. Scale bars, $33 \mu \mathrm{m}$.

\section{Materials and Methods}

Immunocytochemistry. Staged embryos were fixed in $4 \%$ paraformaldehyde, embedded, and sectioned in a cryostat as described previously (Carnahan and Patterson, 1991a). Double labeling was performed using an SA1 ascites fluid diluted 1:2000, together with undiluted B2 hybridoma supernatant (a gift from J. Dodd, Columbia University), polyclonal rabbit anti-TH diluted 1:250 (Eugene Tech Inc., Allendale, NJ), or polyclonal rabbit anti-SCG10 diluted 1:250 (Stein et al., 1988a). Sections were incubated overnight at $4^{\circ} \mathrm{C}$ with primary antibody, in the presence of $1 \%$ normal goat serum (NGS) and $0.1 \%$ Nonidet P-40. After thorough washing to remove unbound primary antibody, sections incubated with SAl plus anti-TH or with SAl plus anti-SCG10 were developed using rhodamine-conjugated goat anti-rabbit IgG at 1:500 plus fluorescein isothiocyanate (FITC)-conjugated goat anti-mouse IgG at 1:200 (TAGO, Inc., Burlingame, CA). Sections incubated with SA1 plus B2 were developed using rhodamine goat anti-mouse IgM (TAGO) and FITC-conjugated goat anti-mouse IgG (Southern Biotech, Inc., Atlanta, GA), both at 1:100. To reduce nonspecific binding, dilutions of secondary antibody were precleared by incubating for $1 \mathrm{hr}$ at $4^{\circ} \mathrm{C}$ in 
$10 \%$ normal rat serum plus $5 \% \mathrm{NGS}$, and then centrifuged for $10 \mathrm{~min}$ at $14,000 \times \mathrm{g}$. Controls lacking primary antibody exhibited no specific staining. Sections were mounted in para-phenylenediamine/glycerol and examined with an Olympus OMT-2 inverted microscope. All micrographs in this article illustrating SA1 versus B2 staining were photographed and printed using identical exposure times, so that staining intensity is directly comparable among the figures. For the detection of phenylethanolamine $N$-methyl transferase (PNMT) immunoreactivity, a rabbit anti-PNMT antiserum (the generous gift of Dr. Martha Bohn, University of Rochester) was used at a dilution of $1: 1000$ and visualized using an FITC-conjugated goat anti-rabbit IgG secondary antibody (TAGO) at 1:200.

Isolation and culture of $\mathrm{B2}^{+}$and $\mathrm{B2}^{-}$cells by $\mathrm{FACS} . \mathrm{B}^{+}$cells were isolated from dissociated suspensions of embryonic day 14.5 (E14.5) adrenal glands by surface labeling and fluorescence-activated cell sorting (FACS) as previously described (Anderson and Axel, 1986). B2- cells were isolated using monoclonal antibody HNK-1 (Abo and Balch, 1981), which labels all $\mathrm{TH}^{+}$cells within the E14.5 adrenal gland (Anderson and Axel, 1986; Birren and Anderson, 1990). We used HNK-1 rather than the $\mathrm{SA}(1,2,4)$ cocktail (Carnahan and Patterson, 1991b) to isolate B2- progenitors, because the SA antigens are poorly expressed on the cell surface in E14.5 adrenal suspensions (J. F. Carnahan, unpublished observations). As all $\mathrm{B} 2^{+}$cells are also $\mathrm{HNK}-1^{+}$, however, in order to isolate the $\mathrm{B}^{-}$fraction the $\mathrm{B} 2^{+}$cells first had to be eliminated by complement lysis using monoclonal antibody B2. The remaining B2cells were then labeled with HNK-1 ascites diluted 1:500 and FITCconjugated goat anti-mouse IgM (TAGO). Virtually all $\mathrm{HNK}-1^{+}, \mathrm{B} 2^{-}$ cells are $\mathrm{TH}^{+}$, and over $80 \%$ are $\mathrm{SA}^{+}$, indicating that $\mathrm{HNK}-1$ (in combination with $\mathrm{B} 2$ elimination) is a sympathoadrenal lineage surface marker comparable to the SA antibodies, for the E14.5 adrenal gland. $\mathrm{B}^{+}$and $\mathrm{HNK}-1^{+}\left(\mathrm{B}^{-}\right)$cells were separated from unlabeled cells by FACS using an Ortho instrument (Becton-Dickinson, Inc., Mountainview, CA). Approximately $1-2 \%$ of the input cells were $B 2^{+}$, while $6-$ $7 \%$ were $\mathrm{B} 2^{-}, \mathrm{HNK}-\mathrm{1}^{+}$. Cells were cultured on a collagen/poly-D-lysine/ laminin substratum in steroid-stripped $\mathrm{L}-15-\mathrm{CO}_{2}$ complete medium as previously described (Anderson and Axel, 1986), except that fetal calf serum was substituted for rat serum. When included, dexamethasone (DEX) was diluted from a stock solution of $10^{-3} \mathrm{M}$ in $95 \%$ ethanol, to a final concentration of $1 \mu \mathrm{M}$. For quantifying the inhibition of process outgrowth, a cell cluster was defined as "process bearing" if any cytoplasmic extension could be detected originating from the cluster. It was not possible to determine whether every cell in a cluster was process bearing, because the tight clumping of the cells precluded assignment of processes to individual cells. Nonetheless, for the purposes of this study this measurement represents a highly stringent criterion, in that only clusters containing exclusively rounded cells were counted as nonprocess bearing. Any systematic error introduced by this method would, if anything, underestimate the difference in process outgrowth between $\mathrm{B} 2-$ and $\mathrm{B} 2+$ cells. For single-cell tracking experiments, cells were identified $24 \mathrm{hr}$ after plating and their positions marked by means of a gridded coordinate system embossed in the bottom of the dish using a $\mathrm{BB}$ press. Cells were photographed at that time and every $24 \mathrm{hr}$ thereafter for the next $2 \mathrm{~d}$.

\section{Results}

Transient coexpression of neuronal- and chromaffin-specific markers by cells in embryonic sympathetic ganglia

In the postnatal rat, the SA1-5 series of monoclonal antibodies specifically labels adrenal chromaffin cells but not sympathetic neurons (Carnahan and Patterson, 1991a). In developing embryos, however, expression of the SA1 antigen is detectable in cells of the primordial sympathetic ganglia, beginning at E11.5 (Fig. 1A; see also Carnahan and Patterson, 1991a). At this time, neural crest cells have aggregated in clusters adjacent to the dorsal aorta and can be recognized by their expression of TH, a lineage marker for adrenergic neural crest derivatives (Cochard et al., 1979). Double labeling indicates that all $\mathrm{SA}_{1}{ }^{+}$cells appear to coexpress $\mathrm{TH}$, and vice versa (Fig. $1 B$ ). No expression of SAl can be detected in premigratory or in migrating neural crest cells $1 \mathrm{~d}$ earlier in development (data not shown).

The initial expression of SA1 coincides not only with that of $\mathrm{TH}$, but also with that of neural-specific markers such as SCG10
(Anderson and Axel, 1985; Stein et al., 1988b) and NF68 (Cochard and Paulin, 1984). To determine whether such neuronal markers are coexpressed in the same cells that express SA1, double-label immunohistochemistry was performed using a rabbit anti-SCG10 antibody (Stein et al., 1988b), mouse monoclonal SAl antibody, and species-specific secondary antibodies. Within the ganglionic cluster, SCG10 (Fig. $1 D$ ) is expressed in an overall pattern that is coextensive with that of SA1 (Fig. 1C). At higher magnification (Fig. $1 E, F$ ), individual cells labeled by both anti-SCG10 and SA1 are visible; many of these cells are process bearing (Fig. $1 E, F$, arrows). It is difficult to determine whether all $\mathrm{SA} 1^{+}$cells are also $\mathrm{SCG} 10^{+}$, however, because the SCG10 antigen is membrane bound (Stein et al., 1988b) and concentrated in the perinuclear region (Fig. $1 D$, arrow) whereas the SA1 antigen exhibits a punctate, cytoplasmic distribution (Fig. 1C, arrowhead). Nevertheless, a substantial number of double-positive cells can be observed. For technical reasons, double labeling with monoclonal SA 1 and NF68 antibodies was not possible. However, the timing of TH and NF68 appearance is coincident (Cochard et al., 1979; Cochard and Paulin, 1984), and TH and NF68 are coexpressed in SA precursors (Anderson and Axel, 1986). It is therefore likely that $\mathrm{SAl}^{+}$ganglionic cells coexpress NF68 as well as SCG10.

The coexpression of SA1, TH, and SCG10 in individual ganglionic cells persists through E12.5 (Fig. $2 A-D$ ). After this time, the expression of SAl in the sympathetic ganglia begins to decline (see also Carnahan and Patterson, 1991a). However, expression of SCG10, TH, and NF is maintained, as previously described (Cochard et al., 1979; Cochard and Paulin, 1984; Anderson and Axel, 1986).

\section{Cells in sympathetic ganglia begin to express $B 2$ coincident with the loss of $S A I$}

Previously, monoclonal antibody B2 (J. Dodd, unpublished observations) was shown to label specifically a population of neuronal precursors in E14.5 sympathetic ganglia, as well as a subset of cells within the adrenal gland (Anderson and Axel, 1986). As B2, like the SA antibodies, appears to be highly specific for cells of the SA lineage, it was of interest to determine the relative timing of expression of these two markers. In contrast to SA1, no staining with B2 can be detected in sympathetic ganglia, or elsewhere in the embryo, at E11.5 (not shown). At E12.5, faint patches of punctate B2 staining can occasionally be seen (Fig. $2 F$ ). These patches overlap some of the $\mathrm{SA}^{+}$cells (Fig. $2 E$ ). Over the next few days of development (E13.5-15.5), the intensity of B2 expression in the sympathetic ganglia increases, while that of SAl decreases (compare exposure-matched Figs. $2 F, 3 B, 4 B$ ), until SA1 expression appears completely replaced by that of $\mathbf{B} 2$.

The increase in B2 expression appears to occur in a rostrocaudal gradient, with more anteriorly located ganglia (Fig. $3 B$ ) expressing higher levels than those located more posteriorly (Fig. $3 D$ ). SA1 staining does not appear to fade in a complementary rostrocaudal manner, however (Fig. $3 A, C$ ). Within "transitional" sympathetic ganglia at E14.5, a complementary pattern of $\mathrm{SA} 1$ and $\mathrm{B} 2$ expression is seen: regions of a given ganglion that are high in SA1 (Fig. 4A, arrow) are low in $\mathrm{B} 2$ (Fig. $4 B$, arrow); conversely, regions that are high in B2 are low in SA1 (Fig. $4 A, B)$. However, the overall domains of SA1 and $\mathrm{B} 2$ expression in such ganglia appear roughly coextensive. By E15.5-16.5, however, virtually all detectable SA1 staining has disappeared, and the ganglia are uniformly strongly $\mathrm{B} 2{ }^{+}$. Taken together, these 


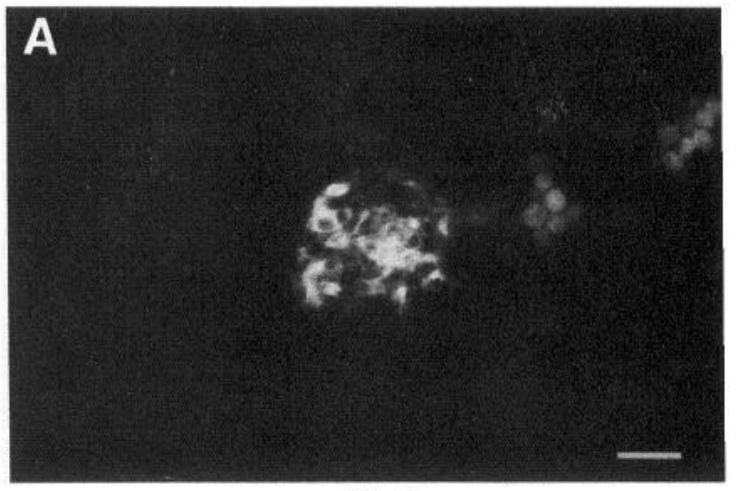

SA-1

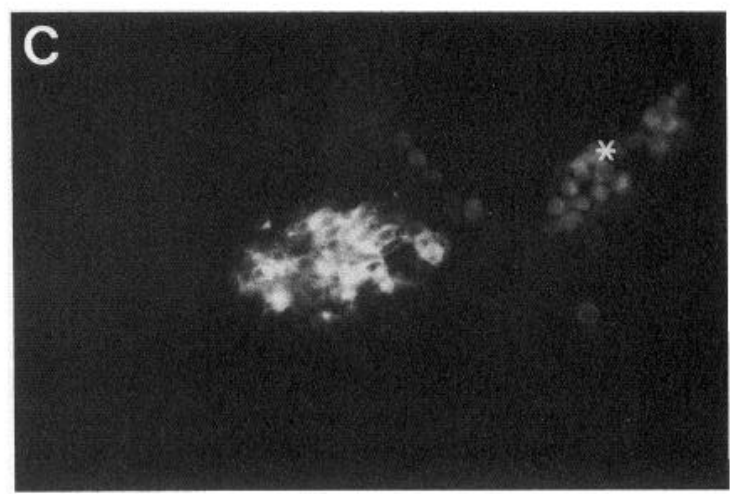

SA-1

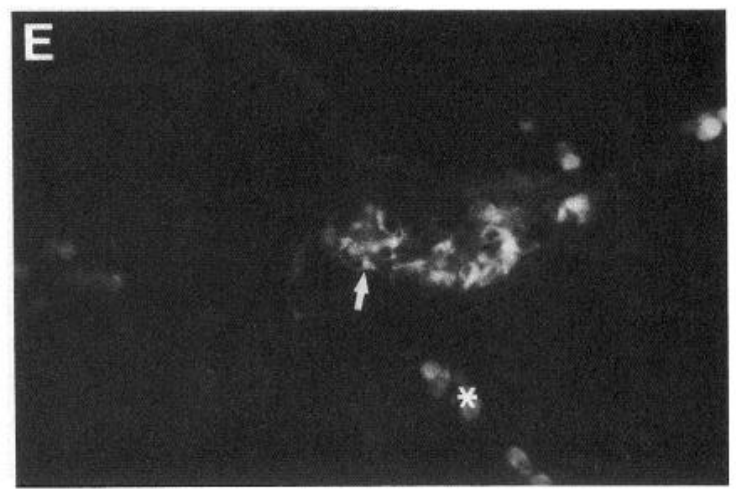

SA-1

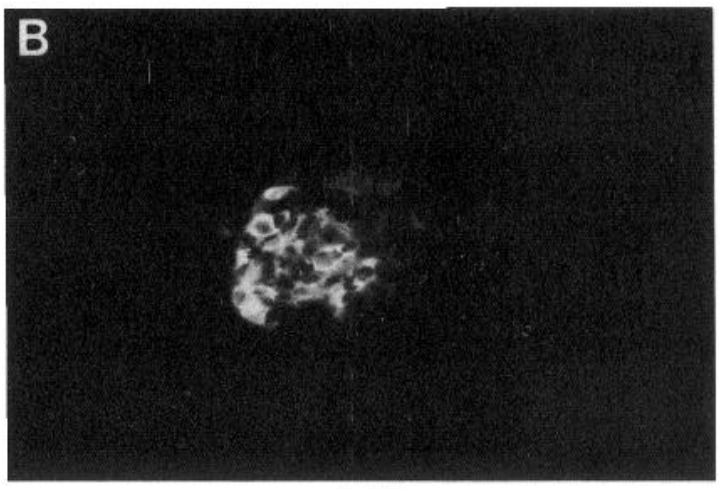

TH

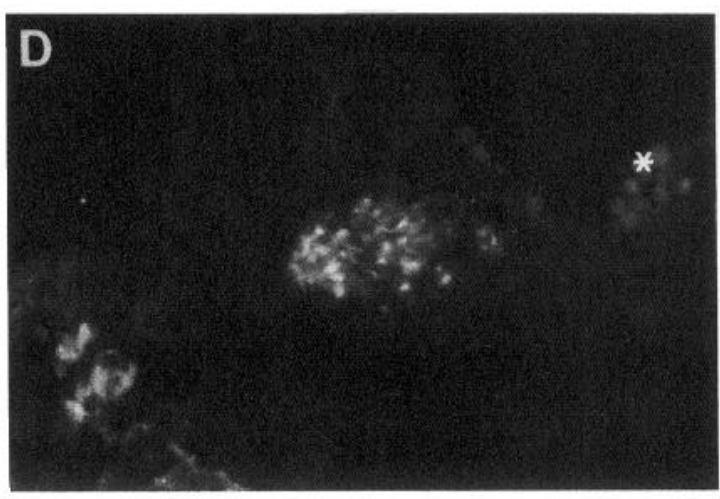

SCG 10

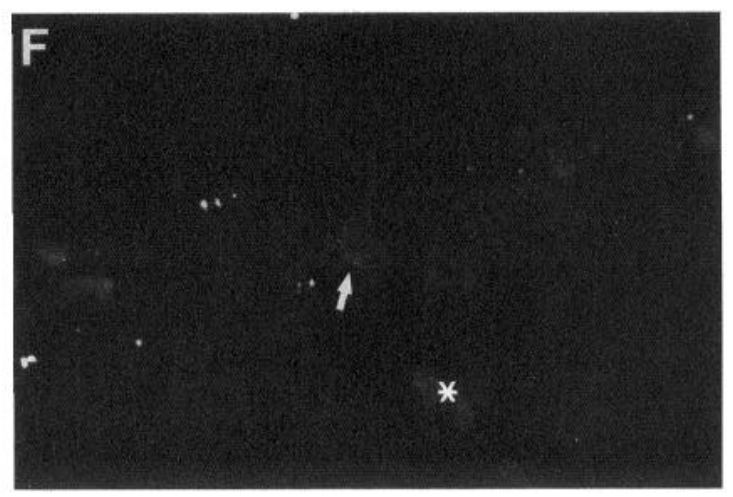

B2

Figure 2. Coexpression of SA1 with TH and SCG10 in E12.5 sympathetic ganglia. $A$ and $B, C$ and $D$, and $E$ and $F$ represent doubly labeled sections stained with the antibodies indicated below the panels. In all cases, the fluorochrome used for SA1 was FITC. In $F$, a faint patch of punctate $\mathrm{B} 2$ staining can be detected in a region containing SA1 ${ }^{+}$cells (arrow, $E$ and $F$ ). However, many ganglia showed no detectable staining with $\mathrm{B} 2$ at this stage of development. Asterisks indicate autofluorescent blood cells. Scale bar, $33 \mu \mathrm{m}$.

data indicate that expression of B2 occurs subsequent to that of SA1 during SA development but that there is a period of transient overlap between these two markers.

\section{The $S A 1 \rightarrow B 2$ transition does not occur in the adrenal medulla}

Chromaffin cells derive from SA progenitors that continue migrating from the vicinity of the sympathetic ganglia to invade the adrenal gland primordium. This invasion begins between E13.5 and E14.5 (Bohn et al., 1981; Teitelman et al., 1982). These invading progenitors express SA 1 (not shown). In contrast to their counterparts in the sympathetic ganglia, however, they appear for the most part to maintain expression of this antigen after settling within the adrenal (Fig. 4C). For example, at E14.5, many cells expressing high levels of SA1 can be observed deep within the adrenal gland (Fig. $4 C, E$; arrowhead), whereas in the adjacent sympathetic ganglion virtually no SAl staining is detectable (Fig. $4 C$, arrow). Conversely, the sympathetic ganglia exhibit a high level of B2 labeling (Fig. $4 D$, arrow), whereas only faint B2 staining is detected within the adrenal gland. In some sections, areas of intense B2 staining could be observed within the adrenal primordium (Fig. $4 F$, arrowhead). However, these regions correspond to the future extraadrenal ganglionic complex (EAGC) (Lempinen, 1964), a structure that segregates from the adrenal gland proper and eventually degenerates toward the end of gestation (Aloe and Levi-Montalcini, 1979).

Cells classified as "chromaffin cells" by histochemical stains have been identified in the embryo in locations outside of the adrenal gland (Lempinen, 1964). Such "extraadrenal chromaffin 


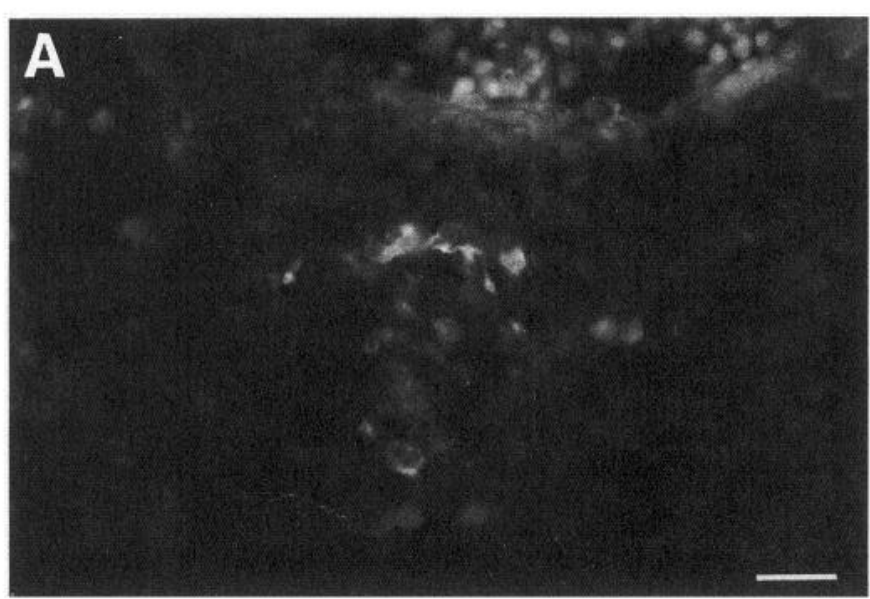

SA-1

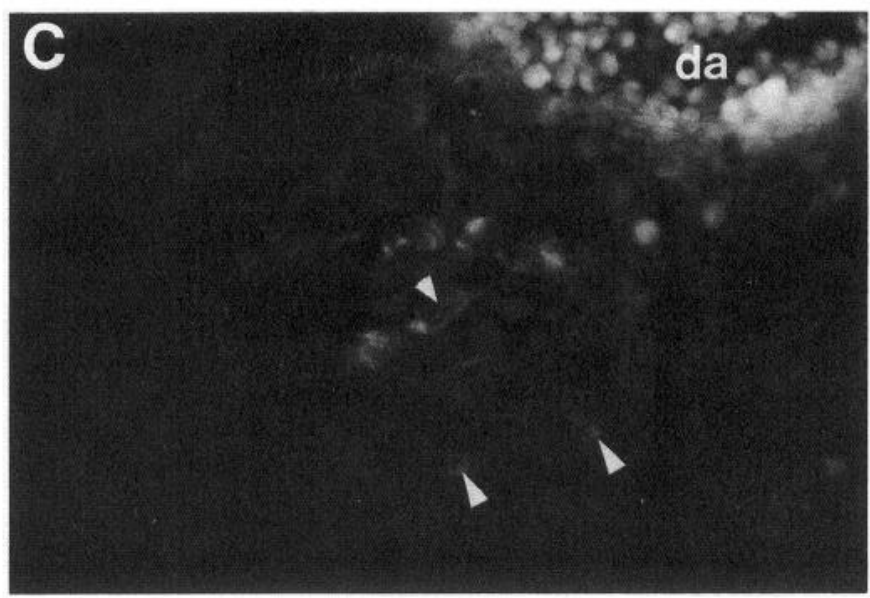

SA-1

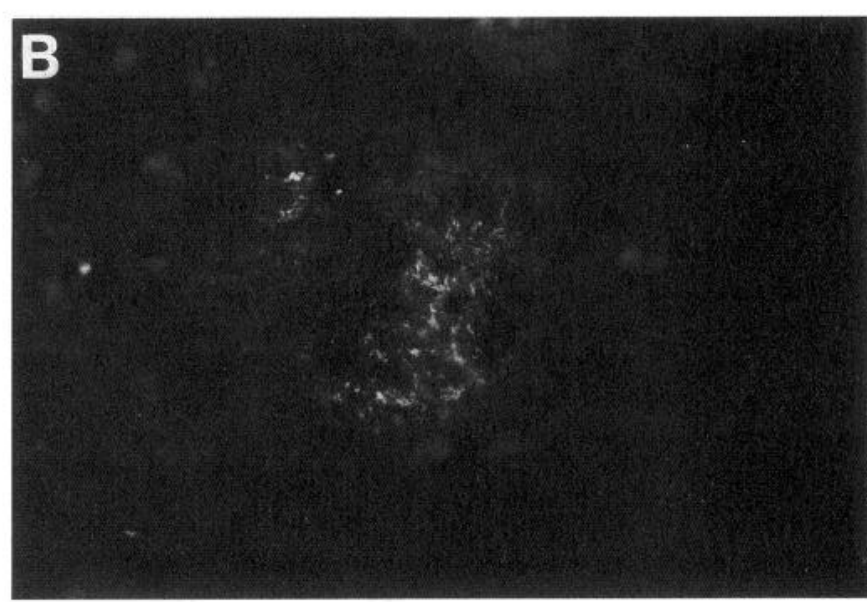

B2

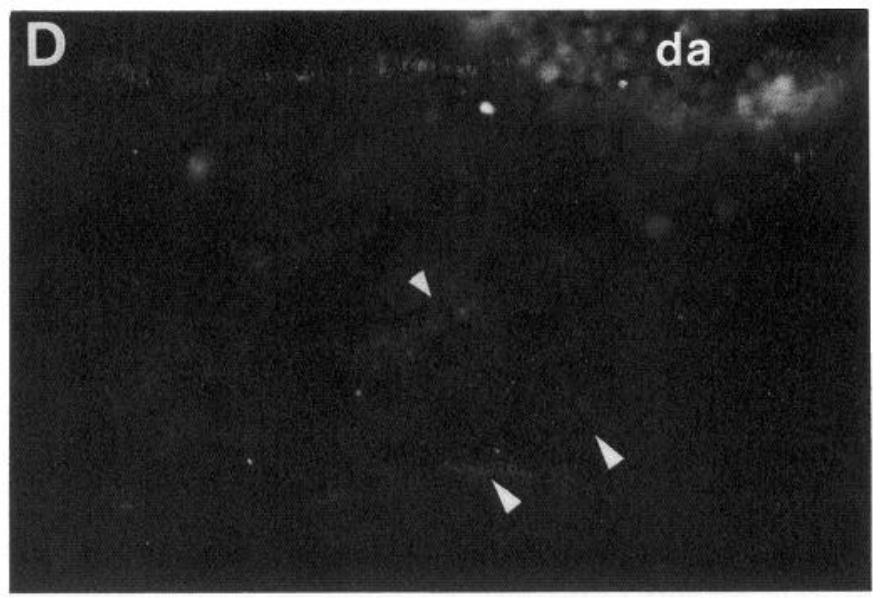

B2

Figure 3. Initial appearance of $\mathrm{B} 2$ in sympathetic ganglia. $A$ and $B$, and $C$ and $D$ represent doubly labeled sections through two different axial levels in the trunk region of an E13.5 embryo. The $A, B$ pair lies more anterior (rostral) than the $C, D$ pair. $A$ and $C$ were photographed and printed using identical exposure times, as were $B$ and $D$. Note that the $\mathrm{B} 2$ staining in $B$ overlaps the region of the sympathetic ganglion containing SA1 ${ }^{+}$ cells in $A$. The B2 staining shows a characteristic punctate appearance. In the more caudally located ganglion $(D)$, the intensity of B2 staining is much weaker (compare with $B$ ). Compare the intensity of $\mathrm{B} 2$ staining in $B$ to that in Figure $2 F$, one day earlier in development. Arrowheads $(C$ and $D$ ) indicate $\mathrm{SA}^{+}$cells that exhibit faint $\mathrm{B} 2$ labeling. $d a$, dorsal aorta. Scale bar, $33 \mu \mathrm{m}$.

cells" also appear to undergo the $\mathrm{SA} 1 \rightarrow \mathrm{B} 2$ transition, like the cells in the sympathetic ganglia but unlike those within the adrenal gland (Fig. 5). For example, clusters of cells expressing SAl can be observed in the paraaortic region (Fig. $5 \mathrm{~A}$, arrows) at E14.5. Patches of $\mathrm{B} 2{ }^{+}$cells are present in some, but not all, of these $\mathrm{SA}^{+}$paraaortic clusters (Fig. $5 B$, arrows). At higher magnification, the domains of $\mathrm{B} 2$ and $\mathrm{SA} 1$ staining appear to be partially overlapping (Fig. $5 C, D$; arrow), similar to the patterns in the transitional sympathetic ganglia (see above).

The appearance of $B 2$ correlates with a loss of competence for chromaffin differentiation

The foregoing data indicated that neuroblasts in the sympathetic ganglia undergo a developmental change beginning on E13.5, in which they gradually extinguish expression of SA1 and acquire expression of B2. By contrast, this change does not appear to occur for the majority of cells that migrate to the adrenal gland. In order to determine whether this change in antigenic phenotype reflects changes in the developmental properties of sympathoadrenal progenitors, we studied in culture the behavior of $\mathrm{B}^{+}$and $\mathrm{B} 2^{-}$cell populations isolated from E14.5 adrenal glands. The adrenal gland was chosen for this experiment because previous studies had indicated that, in addition to the majority B2- chromaffin precursor population, a subset of B2+ cells is present (Anderson and Axel, 1986; see also Fig. 4F); thus, both populations can be obtained from the same tissue. After isolating the $\mathrm{B}^{+}{ }^{+}$cells, the $\mathrm{B} 2^{-}, \mathrm{TH}^{+}$cells were separated from non-SA lineage $\mathrm{B} 2^{-}$cells using monoclonal antibody HNK-1 (see Materials and Methods). This antibody identifies SA lineage cells in the adrenal gland, since all $\mathrm{HNK}-1^{+}$cells are also $\mathrm{TH}^{+}$(Birren and Anderson, 1990). The majority (over $80 \%$ ) of the $\mathrm{B}^{-}, \mathrm{HNK}-1^{+}$cells are also strongly $\mathrm{SA}^{+}$, as determined by staining of fixed, permeabilized cells $(n=300)$. By contrast, $81 \%$ of freshly isolated $\mathrm{B}^{+}{ }^{+}$cells are $\mathrm{SA}^{-}{ }^{-}$. This immunochemical fractionation thus separated the $\mathrm{SA}$ progenitor population from the E14.5 adrenal gland into predominantly $\mathrm{B}^{+}, \mathrm{SA}^{-}$ and $\mathrm{B}^{-}, \mathrm{SAl}^{+}$cells.

$\mathrm{B} 2{ }^{+}$cells appeared more advanced in their state of neuronal differentiation, and less able to develop into chromaffin cells, than the $\mathrm{B}^{-}, \mathrm{SA}^{+}$cells. For example, after $24 \mathrm{hr}$ in culture, 


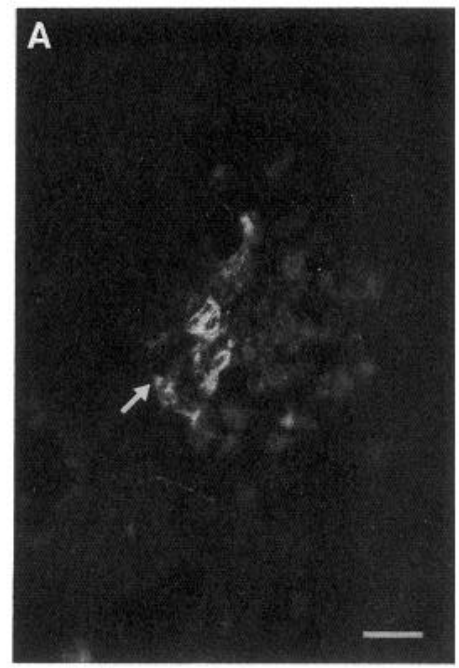

SA-1

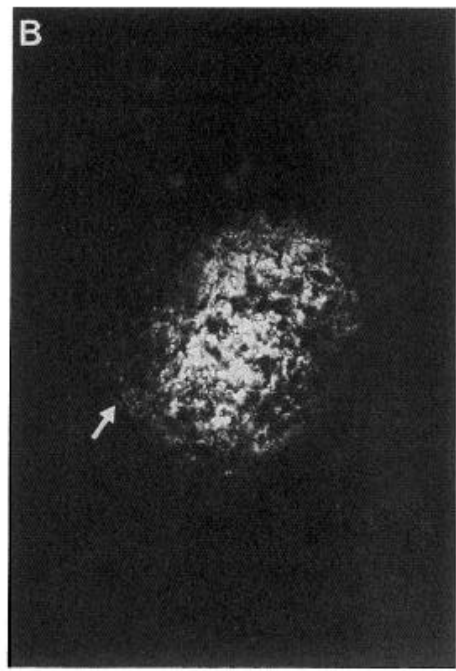

B2

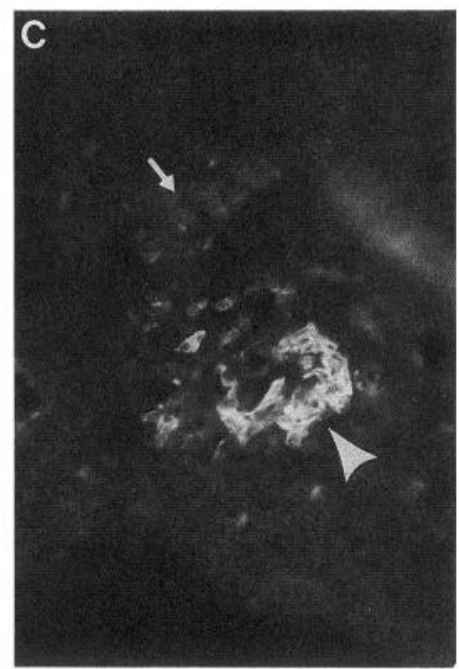

SA-1

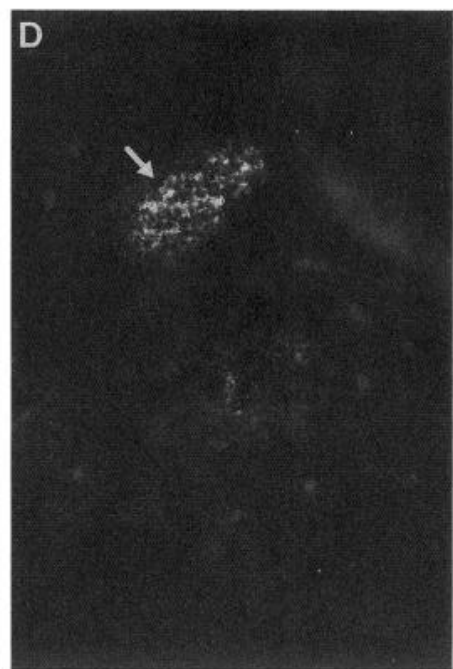

B2

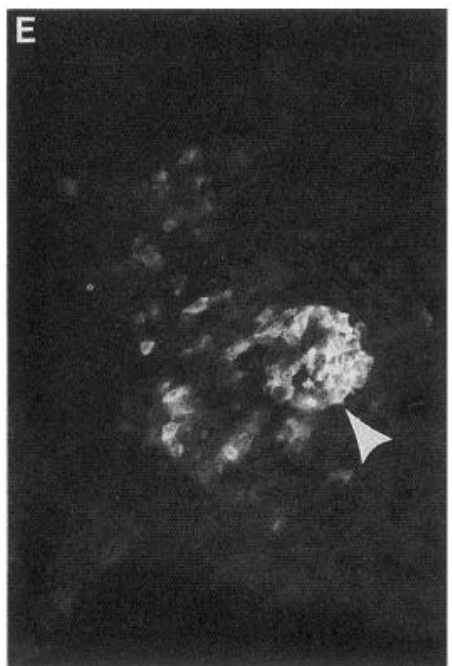

SA-1

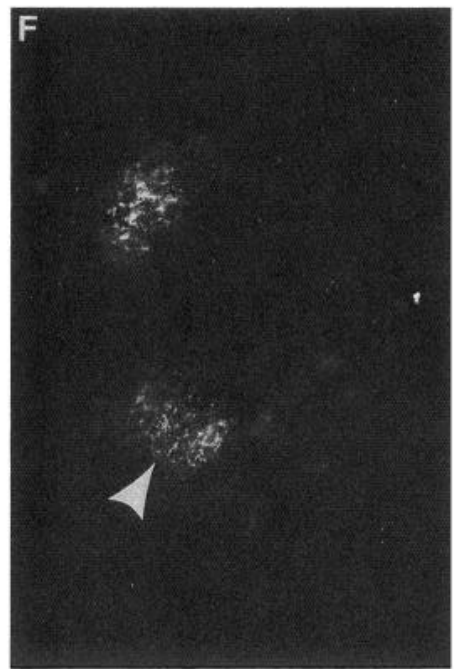

B2

Figure 4. The SA1 $\rightarrow \mathrm{B} 2$ switch occurs in sympathetic ganglia, but not in the adrenal gland. $A$ and $B$, Doubly labeled pair from a section through an E14.5 sympathetic ganglion. Note that the levels of $\mathrm{B} 2$ staining by this stage are quite high (compare with exposure-matched Figs. $2 F$ and $4 B, D$ ). Note also that faint SA1 staining in $A$ can still be detected in the region of the ganglion that is strongly B2+. The arrows indicate a region that is still strongly $\mathrm{SA}^{+}(A)$, but weak for B2 $(B) . C$ and $D$, and $E$ and $F$ represent doubly labeled pairs from two nearby sections through the adrenal gland at E14.5. The arrowheads $\left(C\right.$ and $E$ ) indicate strongly SA1 ${ }^{+}$chromaffin cells deep within the adrenal medullary region. Note that these same regions are negative or only faintly positive for B2 $(D$ and $F)$. The arrows $(C$ and $D)$ indicate the nearby sympathetic ganglion; note the intense B2 staining $(D)$ and low SA1 staining $(C)$. In $F$, the arrowhead indicates a patch of B2+ in the region that will become the EAGC; note that this region also contains some brightly SA1 ${ }^{+}$cells. Photographic exposure times are identical with those in Figures 2 and $4(E$ and $F)$ for SA1 and B2, respectively. Scale bar, $63 \mu \mathrm{m}$.

$81 \%$ of $\mathrm{B} 2+$ cell clusters were process bearing, whereas only $47 \%$ of the B2- clusters bore neurites (Fig. $6 A$, NO ADD). In addition, the processes on $\mathrm{B}^{+}$cells tended to be longer, on average, than those on B2- cells (Anderson, 1988). By day 3, however, 76\% of cell clusters in the B2- population had extended processes (data not shown), indicating that most if not all of these cells are neuronal precursors but that their differentiation lags behind that of the $\mathrm{B} 2{ }^{+}$cells.

The two cell populations also differed significantly in their ability to differentiate into chromaffin cells, as assessed by morphology and antigenic phenotype, in response to the synthetic glucocorticoid DEX. For example, after $24 \mathrm{hr}$ of culture in 1 $\mu \mathrm{M}$ DEX, the majority of B2- cell clusters exhibited a round, chromaffin morphology; only $13 \%$ were process bearing (Fig. $6 A$, DEX, B2-). By contrast, under these same conditions, over $60 \%$ of the $\mathrm{B} 2{ }^{+}$cells bore neurites (Fig. $6 A$, DEX, B2 ${ }^{+}$). Thus, DEX inhibited process outgrowth $72 \%$ in the $\mathrm{B} 2$ - population, but only $24 \%$ in the $\mathrm{B}^{+}$population. Chromaffin differentiation was also assessed by staining cells with antibodies to the chromaffin-specific marker enzyme PNMT. After $3 \mathrm{~d}$ of culture in DEX, over $80 \%$ of the B2- cells exhibited PNMT immunoreactivity, whereas less than $50 \%$ of the $\mathrm{B} 2{ }^{+}$cells expressed PNMT (Fig. 6B). Taken together, these data indicate that the B2- population is less advanced in neuronal differentiation, and has a greater capacity for chromaffin differentiation, than the $\mathrm{B} 2{ }^{+}$population. 


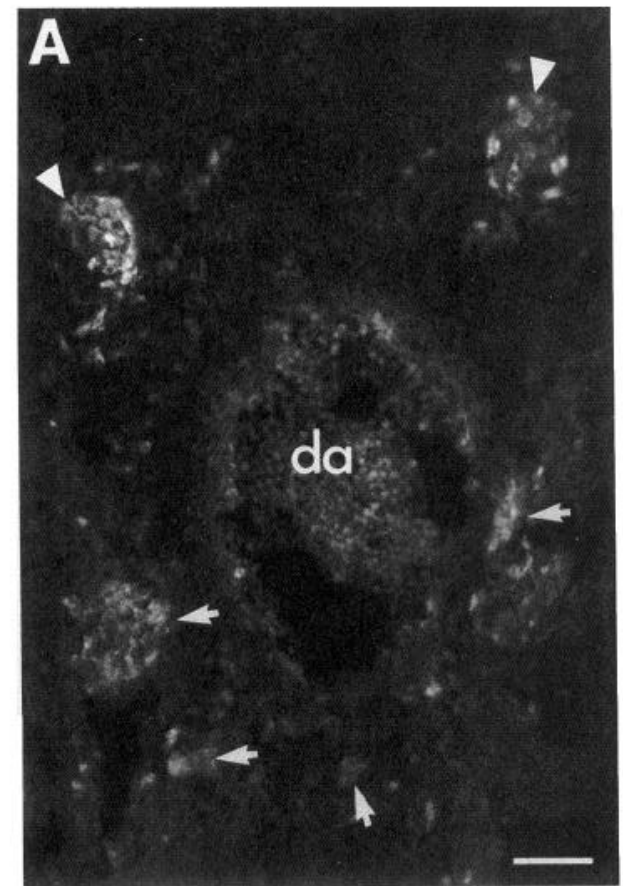

SA-1

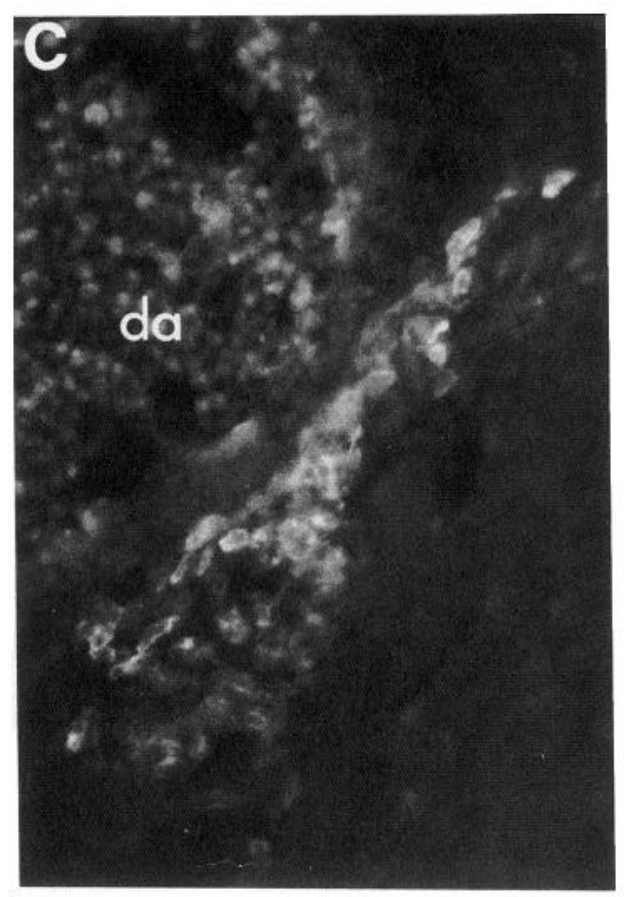

$\mathrm{SA}-1$

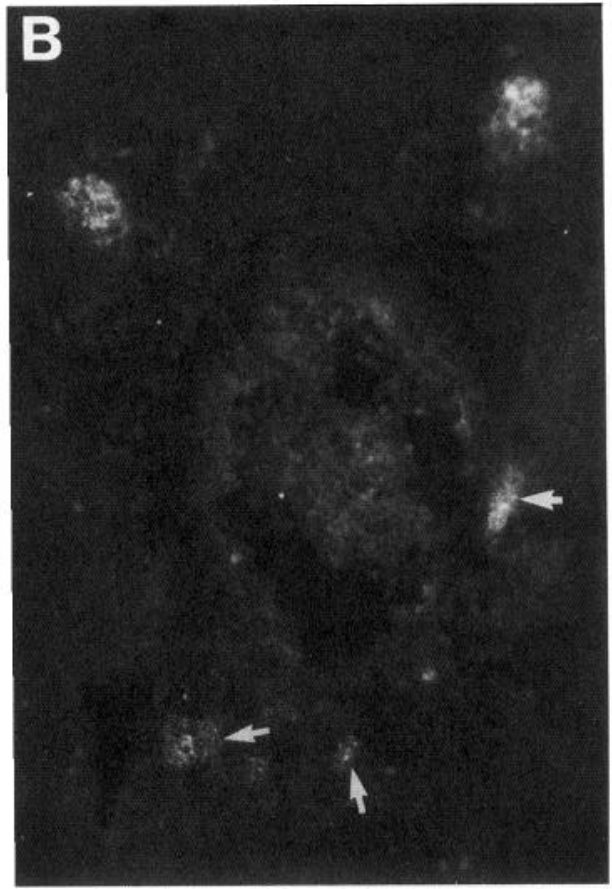

B2

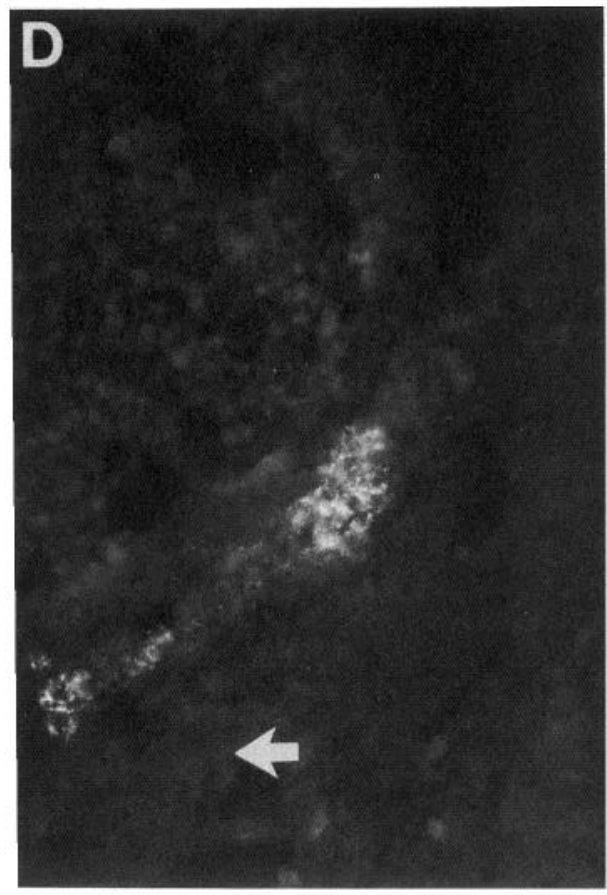

B2
Figure 5. Expression of SA1 and B2 by extraadrenal chromaffin cells in the paraaortic region. $A$ and $B$, and $C$ and $D$ represent doubly labeled pairs from two nearby sections through the lumbar region of an E14.5 embryo, posterior to the region containing the adrenal gland. Arrowheads in $A$ indicate the sympathetic ganglia. da, dorsal aorta. Arrows in $B$ indicate patches of $\mathrm{B} 2{ }^{+}$cells in the paraaortic region; some of these patches are also $\mathrm{SA}^{+}{ }^{+}$in $A$ (arrows). Note, however, a large $\mathrm{SAl}^{+}$patch in $A$ (left arrow) that is not labeled by B2 in $B$. Similar patches in other sections are also labeled by anti-TH and anti-SCG10 (not shown). $C$ and $D$ are a higher-magnification view of paraaortic cells. Note the large patch of $\mathrm{SA}^{+}$cells that is not labeled by $\mathrm{B} 2(D$, arrow), and the intense $\mathrm{B} 2$ staining that overlaps the $\mathrm{SA}^{+}$ region. Scale bar: $134 \mu \mathrm{m}$ for $A$ and $B$; $33.5 \mu \mathrm{m}$ for $C$ and $D$.
Although the $\mathrm{B} 2^{+}$population on average is more advanced in neuronal differentiation than the $\mathrm{B} 2^{-}$population, at the single cell level it is heterogeneous. Previous studies indicated that many $\mathrm{B} 2^{+}$cells continue to extend neurites and then die in glucocorticoid but that a subset of cells can undergo chromaffin differentiation (Anderson and Axel, 1986). Serial observations of identified cells now indicate that these two subpopulations can be identified prospectively by their different morphologies.
We followed the fates of 72 individual B2+ cells in low-density cultures with DEX, over a $3 \mathrm{~d}$ period. Forty-three of these cells were initially process bearing; of those, $86 \%$ died over the ensuing culture period (Fig. 7, arrow). The process-bearing cells that survived did not express detectable PNMT (not shown). On the other hand, of the 19 cells that survived and displayed a chromaffin phenotype, $84 \%$ derived from precursors initially lacking processes (Fig. 7, arrowhead). (The remaining 16\% de- 


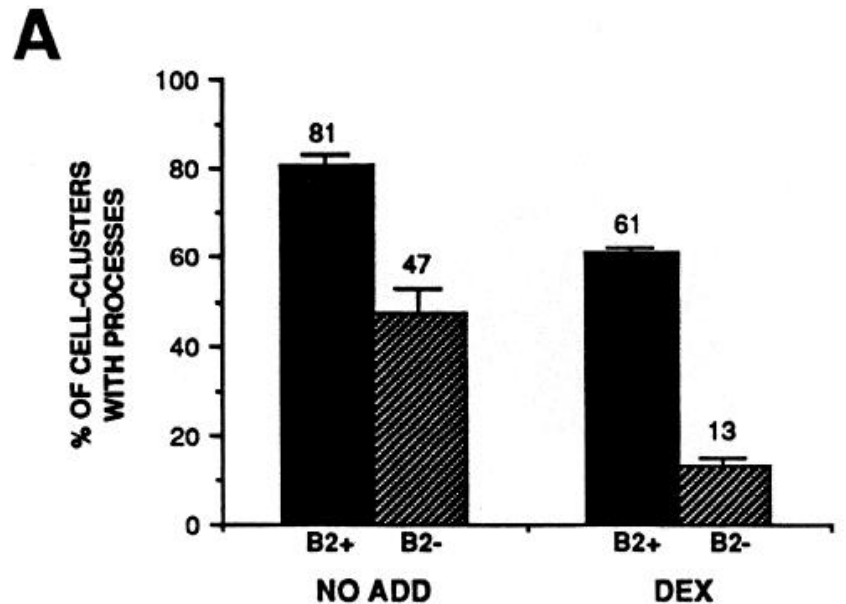

B

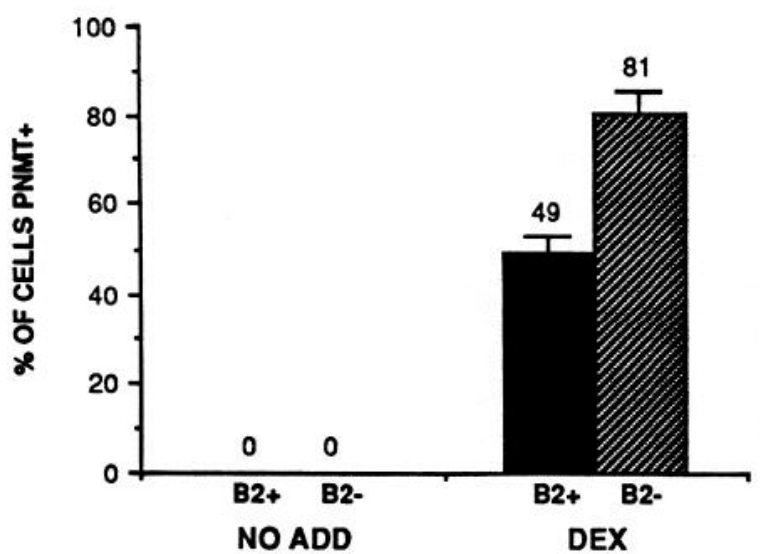

Figure 6. $\mathrm{B} 2{ }^{+}$cells show a reduced capacity for chromaffin differentiation compared to $\mathrm{B}^{-}$cells. $\mathrm{B} 2^{+}$and $\mathrm{B} 2^{-}\left(\mathrm{HNK}-1^{+}\right)$cells were isolated from E14.5 adrenal glands (see Materials and Methods) and cultured with $(D E X)$ or without $(N O A D D) 1 \mu \mathrm{M}$ DEX. $A$, After $24 \mathrm{hr}$ in culture, the population was scored for the percentage of cell clusters bearing processes (see Materials and Methods). Only the $\mathrm{TH}^{+}$cell population was counted; contaminating flat cells were not included. Note that in DEX, only $13 \%$ of B2- clusters had processes, whereas $61 \%$ of $\mathrm{B} 2^{+}$ clusters had processes. The method of analysis probably underestimates the difference between $\mathrm{B}^{+}$and B2- cells (see Materials and Methods). $B$, After $3 \mathrm{~d}$ in culture, the population was fixed and stained with an anti-PNMT antibody, and the percentage of surviving cells expressing PNMT was determined. Time course experiments indicate that most cells that can express PNMT have done so by $3 \mathrm{~d}$ of culture in DEX (Michelsohn and Anderson, unpublished observations). Data are the mean \pm SEM of four to six determinations from two independent experiments.

rived from cells initially bearing short processes.) These data indicate a strong correlation between the initial morphology of B2 ${ }^{+}$cells and their response to glucocorticoid: cells with short processes or a round morphology are likely to survive and differentiate into chromaffin cells, whereas process-bearing cells are likely to continue to extend neurites and then die. The response of SA precursors to glucocorticoid can therefore be predicted based upon a combination of cell morphology and antigenic phenotype.

\section{Expression of $S A 1$ and $B 2$ in late gestational embryos}

The preceding observations revealed a good correlation between the position of SA lineage cells in the embryo and their antigenic phenotype, around E14.5-15.5. Cells that migrate to the adrenal gland maintain expression of SA1 and do not induce B2, whereas cells that migrate to the sympathetic ganglia extinguish expression of SA1 and induce B2. At later stages of gestation, however (ca. E18.5), some violations of this "rule" were observed. For example, scattered patches of $\mathrm{B} 2^{+}$cells can be observed deep within the adrenal medulla (Fig. $8 B$ ). Conversely, patches of $\mathrm{SA}^{+}$cells can be observed outside of the adrenal microenvironment, in the EAGC (Fig. 8C). The EAGC also contains patches of brightly stained $\mathrm{B} 2{ }^{+}$cells (Fig. $8 D$, arrow). However, these patches exhibit a complementary, nonoverlapping distribution relative to the patches of SA $1^{+}$cells (Fig. $8 D$, arrowheads; compare to $8 C$ ). Thus, the mutual exclusivity of high B2 and high SA1 labeling persists, despite the fact that some cells of each phenotype appear in the "inappropriate" location.

$\mathrm{The} \mathrm{SA}^{+}$and $\mathrm{B} 2^{+}$patches can also be distinguished by their relative levels of $\mathrm{TH}$ expression: $\mathrm{SA} 1^{+}$patches are intensely stained with anti-TH antibody (Fig. $8 E, F$ ), whereas $\mathrm{B} 2{ }^{+}$patches are more weakly stained (not shown). B2 ${ }^{+}$patches, conversely, stain more intensely than $\mathrm{SA}^{+}$patches with neuronal markers such as SCG10 and NF68 (not shown). This pattern of marker expression supports the idea that the $\mathrm{B} 2^{+}$patches contain cells with a more neuronal phenotype than the $\mathrm{SA}^{+}$patches.

\section{Discussion}

\section{Evidence for a bipotential SA progenitor in vivo}

Neural crest cells in the ventrolateral migration pathway make a late developmental decision between the expression of an endocrine or a neuronal phenotype. In vitro studies (Doupe et al., 1985b; Anderson and Axel, 1986; Seidl and Unsicker, 1989b; Carnahan and Patterson, 1991b) have provided evidence that this decision is made by a progenitor cell whose choice of cell fate is determined, at least in part, by environmental factors. However, it has been difficult to verify this lineage relationship in vivo, because of the difficulties involved in tracing the fates of migratory cells in the mammalian embryo. In this study, we report the observation that at least some cells in embryonic sympathetic ganglia transiently coexpress neural-specific and chromaffin-specific markers. Cells that remain in the ganglion primordia lose expression of the chromaffin markers (SA1-5) and retain expression of the neuronal markers. Conversely, cells that migrate to the adrenal primordium lose expression of the neuronal markers (Anderson and Axel, 1986; Vogel and Weston, 1990) and retain expression of SA1-5. These data are consistent with the idea that the transiently dual-phenotype cells are bipotential progenitors of chromaffin cells and sympathetic neurons, which selectively repress expression of the neuronal or chromaffin markers according to their final choice of cell fate.

An alternative explanation is that the disappearance of SA1 immunoreactivity from the ganglion primordium at E14.5 is due to the death or emigration of SA 1 + cells. This seems unlikely, because initially the $\mathrm{SA}^{+}$cells are also $\mathrm{TH}^{+}$and $\mathrm{SCG}_{10}{ }^{+}$, and cells with a $\mathrm{TH}^{+}, \mathrm{SCG}_{10} 0^{+}$phenotype remain in the ganglia even as SA1 disappears. Moreover, we observe the concomitant appearance of a second marker, B2, in cells that are still weakly $\mathrm{SA}^{+}$(see below). Thus, the cells that are initially $\mathrm{SA}^{+}$appear to remain in the ganglion primordium and to change their antigenic phenotype, rather than to disappear. Furthermore, the 
isolation of $\mathrm{SA}_{1}{ }^{+}$cells from E13.5 sympathetic ganglia has revealed that $90 \%$ of these cells initially express neurofilament $140 \mathrm{kDa}$ and that these cells have the capacity to develop either into chromaffin cells or sympathetic neurons, depending upon culture conditions (Carnahan and Patterson, 1991b). Taken together, these data indicate that the $\mathrm{SA}^{+}$, $\mathrm{SCG10}{ }^{+}$cells observed in embryonic sympathetic ganglia are likely to be precursors of sympathetic neurons in vivo.

The phenomenon of transient marker coexpression followed by mutually exclusive segregation is reminiscent of several other cell lineages, wherein bi- or multipotential progenitors have been shown to give rise to closely related but distinct cell types. In the immune system, for example, $\mathrm{CD}^{+}$and $\mathrm{CD} 8^{+}$peripheral T-lymphocytes have been shown to derive from a progenitor that is initially double positive for both of these cell-surface markers (Carbone et al., 1988; Fowlkes et al., 1988). In the pituitary gland, somatotrophs expressing growth hormone and lactotrophs expressing prolactin are thought to develop from precursors that transiently coexpress both hormones (Hoeffler et al., 1985). Finally, in the endocrine pancreas, embryonic islet progenitor cells have been shown to initially coexpress peptides, such as insulin and glucagon, which later segregate to different subpopulations of mature endocrine cells (Alpert et al., 1988).

This phenomenon could reflect the fact that the coexpressed genes are regulated, in part, by transcription factors that are common to all cells of a given lineage (Bodner et al., 1988; Ingraham et al., 1988). The later restriction of these markers to different subtypes of cells within the lineage could reflect the superposition of additional regulatory mechanisms, which finetune the pattern of gene expression. In the SA lineage, for example, the expression of neuronal markers such as SCG10 can be upregulated by fibroblast growth factor (FGF) and NGF (factors which promote neuronal differentiation) and downregulated by glucocorticoid (which promotes chromaffin differentiation) (Stein et al., 1988a). Conversely, chromaffin-abundant markers such as TH (Fig. $8 E, F$ ) are upregulated by glucocorticoid and downregulated by NGF (Leonard et al., 1987; Stein et al., 1988a). In this way, a repertoire of lineage-specific gene expression established in progenitor cells by a common transcriptional program may be fine-tuned by differences in local environment, generating further phenotypic diversification.

\section{Developing sympathetic neuroblasts undergo a switch in antigenic phenotype}

Our antibody markers revealed a relatively late developmental event in the differentiation of sympathetic ganglionic neuroblasts: as expression of the SAl antigen declines, the cells induce the expression of a surface antigen recognized by monoclonal antibody B2. At intermediate times, both SA1 and B2 are expressed in the same ganglia, and the pattern of expression of these two markers appears coextensive. Eventually, SA1 expression becomes undetectable and the cells in the ganglia uniformly express high levels of B2. This pattern strongly suggests that the $\mathrm{SA} 1 \rightarrow \mathrm{B} 2$ transition reflects a change in marker expres-

Figure 7. B2 ${ }^{+}$cells bearing processes fail to respond to glucocorticoid Individual B2 ${ }^{+}$cells were identified $24 \mathrm{hr}$ after plating in $1 \mu \mathrm{M}$ DEX and photographed every $24 \mathrm{hr}$ for the next $2 \mathrm{~d}$. Numbers indicate hours of culture. Arrows indicate an example of a pair of process-bearing cells that failed to respond to DEX. Note at $48 \mathrm{hr}$ the phase-bright pycnotic figures near the remaining two phase-gray living cells, suggestive of cell
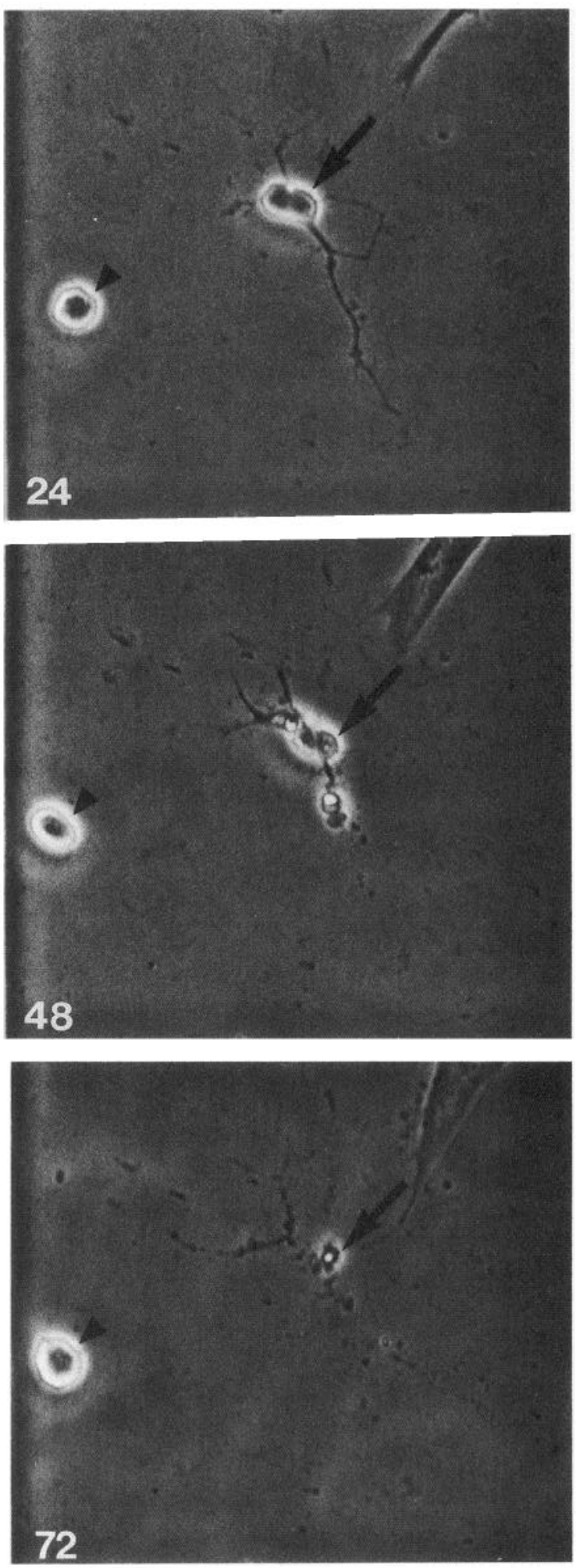

division followed by cell death. At $72 \mathrm{hr}$, only a single pycnotic figure is visible (arrow). The arrowhead indicates an example of a non-processbearing cell (or cell cluster) that survived and displayed a rounded chromaffin morphology. Antibody staining indicated that cells of this phenotype were PNMT $^{+}$(not shown). Note that process-bearing cells were also observed to die in cultures lacking DEX (not shown), indicating that the death of these cells is not caused by glucocorticoid. The extent of cell death is greater in the low-density cultures used in these single-cell tracking experiments than in the mass cultures used in population experiments; therefore, the results of the two types of experiments are not quantitatively comparable. 


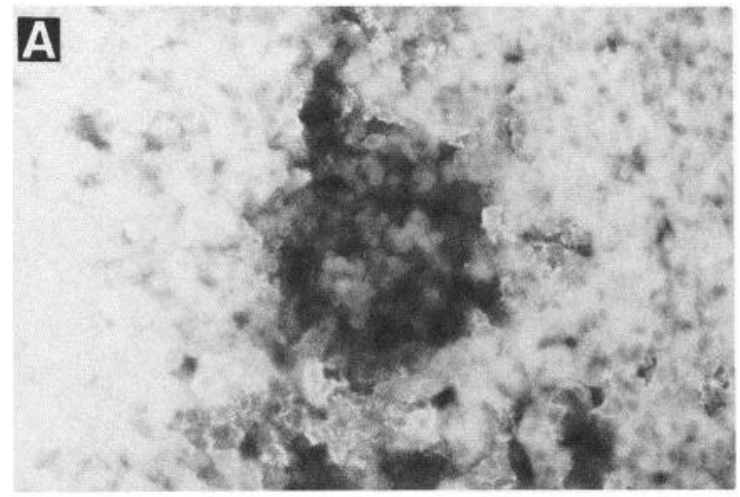

SA-1

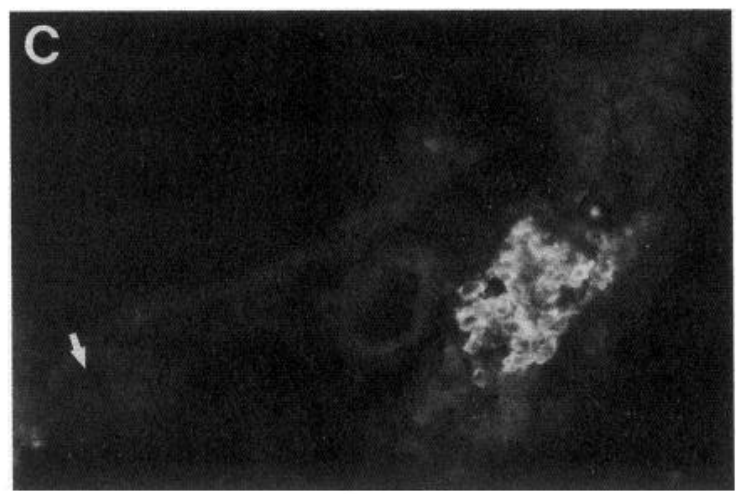

SA-1

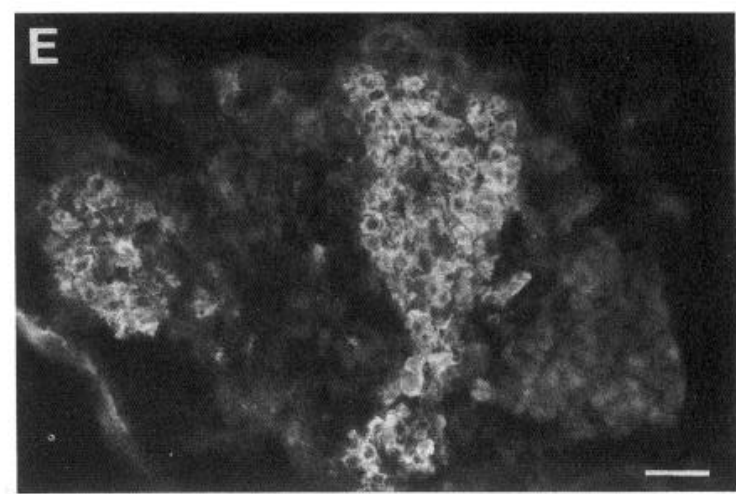

SA-1

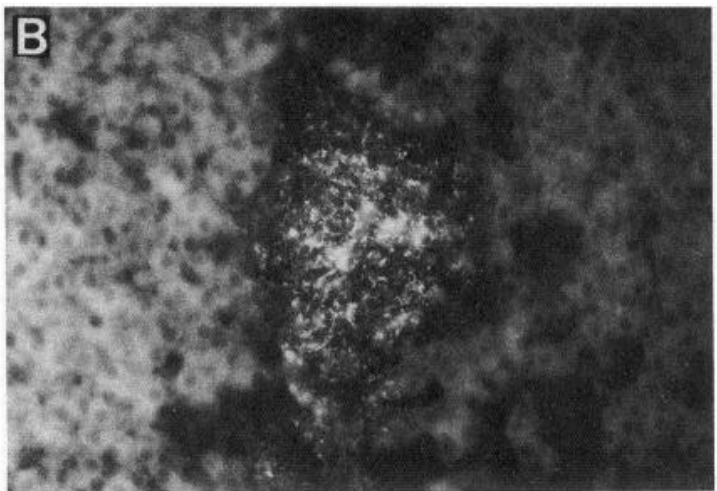

B2

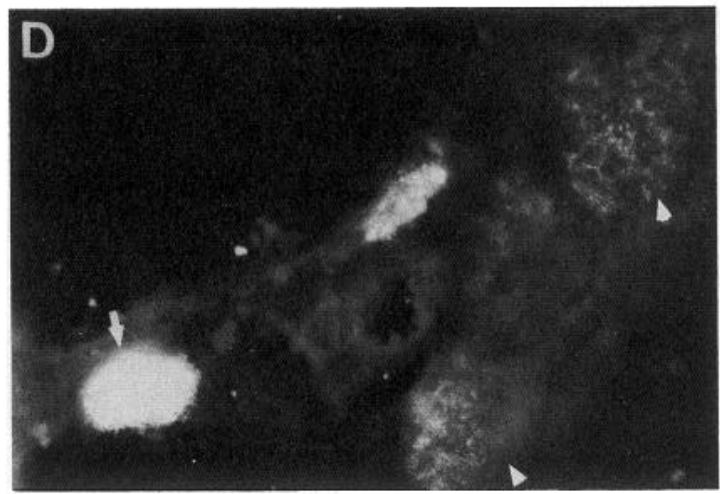

B2

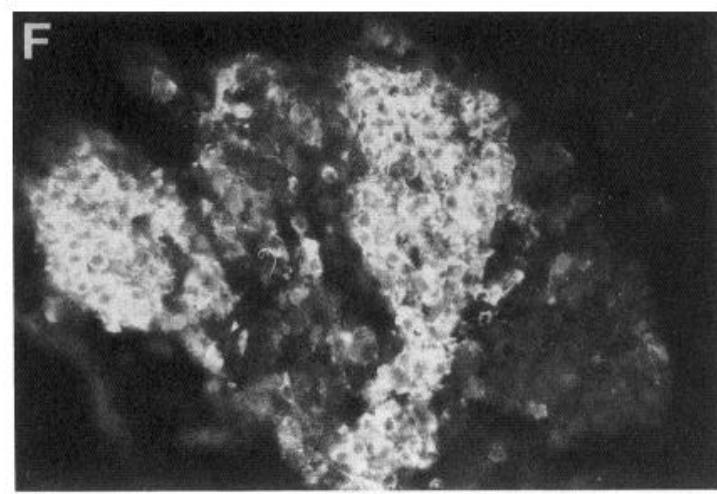

$\mathrm{TH}$

Figure 8. Patches of $\mathrm{B} 2^{+}$and SA1+ cells that violate the positional "rule." Shown are sections from an E18.5 embryo. $A$ and $B$, Doubly labeled pair through the adrenal gland. Note the large patch of B2+ cells $(B)$, which is $\mathrm{SA}^{-}(A)$. In $A$, the SA1 staining is obscured by a high level of autofluorescence but is clearly visible as punctate labeling at the margin of the B2+ zone. $C$ and $D$, Doubly labeled pair through the extraadrenal ganglionic region. Note the intensely stained patch of B2 ${ }^{+}$cells (arrow, D), which is SA1- (arrow, C). Arrowheads in D indicate two less-intensely stained $\mathrm{B} 2{ }^{+}$patches, which flank a SA1 ${ }^{+}$patch $(C) . E$ and $F$, Doubly labeled pair through an EAGC, illustrating adjacent patches of $\mathrm{SA}^{+}$, $\mathrm{TH}^{\text {hi }}$ cells, and SA1-, $\mathrm{Th}^{\circ}$ cells. The SA1- patches would be B2+ (as, e.g., in $C$ and $D$, arrowheads). Scale bar, $62 \mu \mathrm{m}$.

sion within a single population of cells, rather than the replacement of one population by another. This interpretation is reinforced by the complementary patterns of SA1 and B2 staining seen within individual transitional ganglia: regions that are intensely $\mathrm{SA}^{+}$are weakly $\mathrm{B}^{+}$, and vice versa. Such nonhomogeneous staining further suggests that the $\mathrm{SA} 1 \rightarrow \mathrm{B} 2$ switch occurs asynchronously for cells within a given ganglion.

The $\mathrm{SA} 1 \rightarrow \mathrm{B} 2$ transition provides an indication that the cells of the developing sympathetic ganglia are changing, in a way that is not otherwise detectable in vivo. In what way are the cells changing? The fact that expression of SA1 precedes that of B2 suggests that cells expressing the former antigen are at an earlier stage of neuronal differentiation than cells expressing the latter. Consistent with this idea, cells isolated by sorting with a cocktail of SA antibodies have a rounded morphology (Carnahan and Patterson, 1991b), whereas cells isolated by sorting with B2 tend to extend processes shortly after plating (Anderson, 1988). Moreover, most $\mathrm{B}^{-}, \mathrm{SA}^{+}$cells can be induced to differentiate into chromaffin cells at high frequency by glucocorticoid (see also Carnahan and Patterson, 1991b). By contrast, process-bear- 
ing $\mathrm{B}^{+}{ }^{+}$cells are refractory to such an induction. As demonstrated previously (Anderson and Axel, 1986), a minority of B2+ cells remain responsive to glucocorticoid, but most of these cells initially exhibit a rounded morphology. The developmental heterogeneity within the adrenal $\mathrm{B} 2^{+}$population is consistent with the fact that $19 \%$ of freshly isolated $\mathrm{B} 2{ }^{+}$cells express SA 1 . This could reflect the gradual nature of the $\mathrm{SA} 1 \rightarrow \mathrm{B} 2$ transition, as suggested by the overlapping expression of SA1 and B2 in sections of E14.5 sympathetic ganglia. Nevertheless, cells with a $\mathrm{B}^{+}, \mathrm{SA}^{-}$antigenic phenotype and a process-bearing morphology have lost competence to respond to glucocorticoid and appear committed to neuronal differentiation (Fig. 9). The loss of responsiveness to glucocorticoid may serve to "insulate" immature sympathetic neurons from the steep rise in circulating fetal corticosterone levels, which begins on E16.5 (Teitelman et al., 1982). Loss of competence is thought to be a feature of inductive processes in other embryonic systems (Gurdon, 1987; Grainger and Gurdon, 1989).

\section{Control of the $S A 1 \rightarrow B 2$ transition}

Cells that arrest migration in the sympathetic ganglia extinguish $\mathrm{SA} 1$ and induce $\mathrm{B} 2$, whereas those that migrate into the adrenal primordium mostly fail to make this switch. Instead, chromaffin cells maintain expression of SA1 into adulthood. This observation suggests that the $\mathrm{SA} 1 \rightarrow \mathrm{B} 2$ switch may be controlled by factors in the microenvironments encountered by SA progenitors. SA antigen-positive progenitors from sympathetic ganglia reduce levels of SA1 expression in the absence of DEX but maintain expression in the presence of DEX (Carnahan and Patterson, 1991b). Moreover, chromaffin cells from neonatal rats lose SA staining in the presence of NGF and absence of glucocorticoid (Carnahan and Patterson, 1991a). These in vitro results suggest that in vivo, progenitors within the adrenal primordium may be prevented from undergoing the SA $1 \rightarrow \mathrm{B} 2$ transition by the high local concentration of adrenal corticosteroids. The SA1 $\rightarrow$ B2 transition may also be promoted by factors that stimulate neuronal differentiation, such as FGF and NGF (Stemple et al., 1988; Birren and Anderson, 1990; Carnahan and Patterson, 1991b).

The maintenance of SA1 and failure to induce B2 are first apparent in the adrenal gland as early as E14.5 (Fig. 4), suggesting that glucocorticoids and their receptor are functional at this early stage. mRNA encoding the glucocorticoid receptor has been detected in the adrenal gland as early as E15.5 (Anderson and Michelsohn, 1989). However, using a radioligand binding assay, Seidl and Unsicker (1989b) have reported that glucocorticoid receptor is undetectable in adrenal medullary precursors prior to E16.5. The reason for this apparent discrepancy is not clear. Chromaffin precursors may contain a low level of receptor that is sufficient to mediate the inhibition of neuronal differentiation; alternatively, the $\mathrm{SA} 1 \rightarrow \mathrm{B} 2$ transition may be suppressed in the early adrenal gland by factors other than steroid hormones. However, recent radioimmunoassay data indicate that the E14.5 adrenal gland contains micromolar quantities of glucocorticoid (A. Michelsohn and D. J. Anderson, unpublished observations). Whatever the case, the SA1 and B2 markers provide evidence that progenitors in the adrenal gland are phenotypically distinct from their ganglionic counterparts 2 $\mathrm{d}$ before they express PNMT, the only other marker previously able to distinguish chromaffin cells from sympathetic neurons (Bohn et al., 1981; Teitelman et al., 1982).

The correlation between the antigenic phenotype of SA pro-

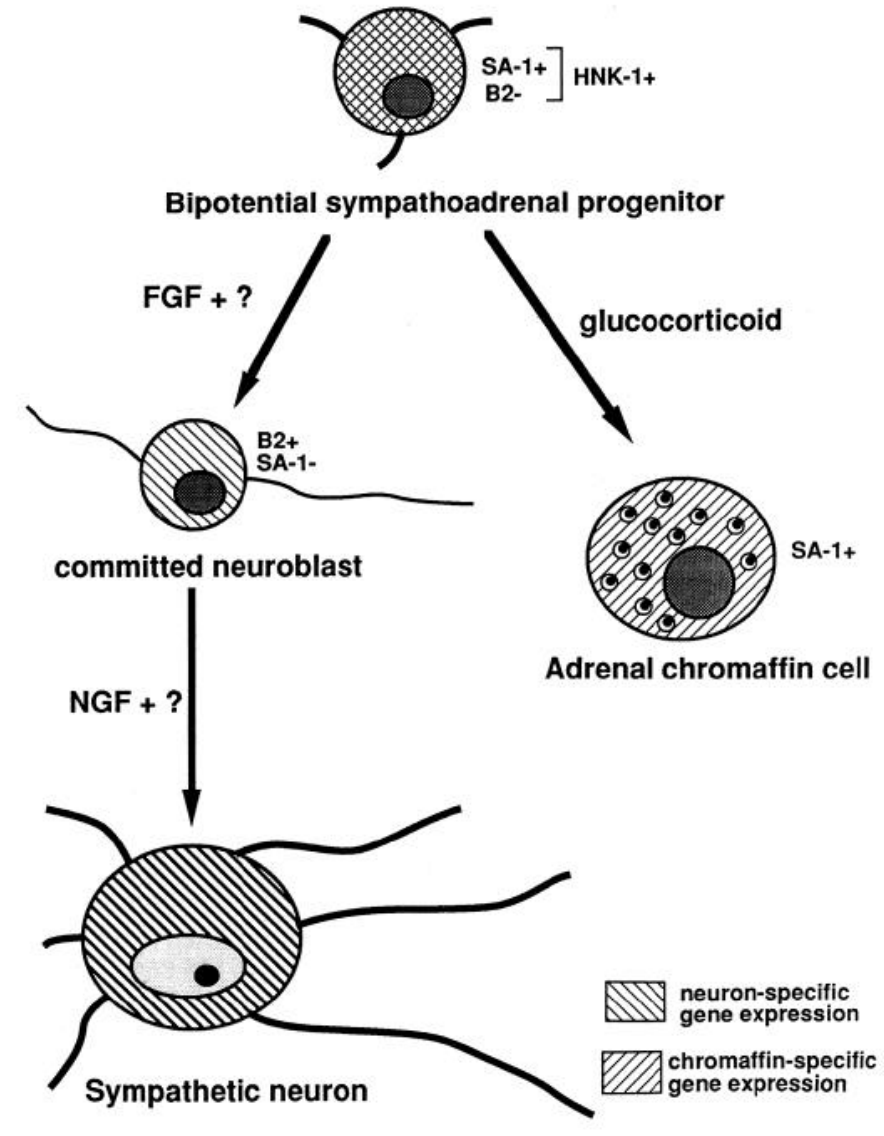

Figure 9. Schematic diagram illustrating sequence of antigenic changes in the SA lineage. The earliest bipotential progenitors are $\mathrm{SA}^{+}$and B2- . They coexpress neuron-specific markers such as SCG10 and chromaffin-specific markers such as SA1-5, as illustrated by the crosshatching. In this study, progenitor cells were isolated from E14.5 adrenal glands using monoclonal antibody HNK-1 in combination with B2mediated complement lysis. Most but not all of these cells are also SAl ${ }^{+}$; those cells lacking SA1 may have initiated neuronal differentiation. In the absence of glucocorticoids, these progenitors differentiate along the neuronal pathway, a process promoted by FGF and perhaps other, as yet unidentified factors. Cells that are $\mathrm{B}^{+}$and $\mathrm{SA}^{-}$and that bear processes have lost competence to respond to glucocorticoid (committed neuroblast). For clarity, intermediate stages of development between the bipotential progenitor and committed neuroblast are omitted.

genitors and their location in the embryo is not perfect: occasional clusters of $\mathrm{B} 2{ }^{+}$cells can be found within the adrenal gland, and clusters of SA $1^{+}$cells are found outside of it, late in gestation. The B2+ clusters probably correspond to clusters of Neuropeptide $\mathrm{Y}^{+}$cells observed by Henion and Landis (1990). Similar clusters of cells with a neuronal phenotype have been found within the human fetal adrenal gland as well (Cooper et al., 1990). Our in vitro results provide a possible explanation for this phenomenon: these $\mathrm{B} 2{ }^{+}$neuronal cells derive from precursors that have lost competence to respond to glucocorticoid, either prior to or shortly after migration to the adrenal primordium. The majority of these cells disappear by the first postnatal week, probably being eliminated by cell death (Henion and Landis, 1989).

By the same token, at E18.5 some $\mathrm{SA}^{+}$cells can be found outside of the adrenal environment. Since the $\mathrm{SA} 1 \rightarrow \mathrm{B} 2$ switch appears to occur slowly and asynchronously, these cells may 
have failed to induce B2 by E16.5 and then have been prevented from doing so subsequently by the surge in fetal GC levels that occurs on E16.5-17.5 (Teitelman et al., 1982). The decision to retain the SA1 antigen may, moreover, become stabilized with further chromaffin development. Interestingly, the $\mathrm{SA}^{+}$cells in the paraaortic and extraadrenal region are found in clusters, as are the $\mathrm{B} 2{ }^{+}$cells. This suggests that once cells decide whether or not to make the $\mathrm{SA} 1 \rightarrow \mathrm{B} 2$ switch, they may reinforce their immediate neighbors to do likewise. Such a "community effect" has been demonstrated for the process of mesodermal induction in Amphibia (Gurdon, 1988). Alternativcly, such clusters could reflect an aggregation (Henion and Landis, 1990) or clonal expansion of phenotypically similar cells.

Using a series of antibody markers, we have defined a sequence of events during the development of the SA lineage in the rat embryo (Fig. 9). Bipotential SA progenitors initially coexpress both chromaffin-specific and neuron-specific markers and then differentiate into neurons or endocrine cells depending upon the environment to which they migrate. Subsequently, additional changes in marker expression are detected: cells in the sympathetic ganglia switch from an $\mathrm{SA}_{1}{ }^{+}$to a $\mathrm{B} 2{ }^{+}$phenotype, whereas this switch fails to occur for the majority of cells within the adrenal gland. Studies of isolated SA progenitors in vitro indicate that this switch correlates with a loss of competence to respond to glucocorticoids, an inducing signal for chromaffin differentiation. Taken together, these data indicate that the development of sympathetic ncurons and adrenal chromaffin cells is controlled not only by environmental signals, but also by changes in the ability of cells to respond to such signals. Such changes illustrate one way in which the developmental capacities of initially multipotent cells can become restricted during differentiation.

\section{References}

Abo T, Balch CM (1981) A differentiation antigen of human NK and $\mathrm{K}$ cells identified by a monoclonal antibody (HNK-1). J Immunol 127:1024-1029.

Aloe L, Levi-Montalcini R (1979) Nerve growth factor-induced transformation of immature chromaffin cells in vivo into sympathetic neurons: effects of antiserum to nerve growth factor. Proc Natl Acad Sci USA 76:1246-1250.

Alpert S, Hanahan D, Teitelman G (1988) Hybrid insulin genes reveal a developmental lineage for pancreatic endocrine cells and imply a relationship with neurons. Cell 53:295-308.

Anderson DJ (1988) Cell fate and gene expression in the developing neural crest. In: Neural development and regeneration, NATO ASI series, Series H, Vol 22 (Gorio A, ed), pp 188-198. Berlin: Springer.

Anderson DJ, Axel R (1985) Molecular probes for the development and plasticity of neural crest derivatives. Cell 42:649-662.

Anderson DJ, Axel R (1986) A bipotential neuroendocrinc precursor whose choice of cell fate is determined by NGF and glucocorticoids. Cell 47:1079-1090.

Anderson DJ, Michelsohn A (1989) Role of glucocorticoids in the chromaffin-neuron developmental decision. Int J Dev Neurosci 12: 83-94.

Birren SJ, Anderson DJ (1990) A v-myc-immortalized sympathoadrenal progenitor cell line in which neuronal differentiation is initiated by FGF but not NGF. Neuron 4:189-201.

Bodner M, Castrillo J-L, Theill LE, Deerinck T, Ellisman M, Karin M (1988) The pituitary-specific transcription factor GHF-1 is a homeobox-containing protein. Cell 55:505-518.

Bohn MC, Goldstein M, Black IB (1981) Role of glucocorticoids in expression of the adrenergic phenotype in rat embryonic adrenal gland. Dev Biol 82:1-10.

Carbone AM, Marrack P, Kappler JW (1988) Demethylated CD8 gene in $\mathrm{CD}^{+} \mathrm{T}$ cells suggests that $\mathrm{CD} 4{ }^{+}$cells develop from $\mathrm{CD}^{+}$precursors. Science 242:1174-1176.
Carnahan JF, Patterson PH (1991a) The generation of monoclonal antibodies that bind preferentially to adrenal chromaffin cells and the cells of embryonic sympathetic ganglia. J Neurosci 11:3493-3506.

Carnahan JF, Patterson PH (1991b) Isolation of the progenitor cells of the sympathoadrenal lineage from embryonic sympathetic ganglia with the SA monoclonal antibodies. J Neurosci 11:3520-3530.

Cochard P, Paulin D (1984) Initial expression of neurofilaments and vimentin in the central and peripheral nervous system of the mouse embryo in vivo. J Neurosci 4:2080-2094.

Cochard P, Goldstein M, Black IB (1979) Initial development of the noradrenergic phenotype in autonomic neuroblasts of the rat embryo in vivo. Dev Biol 71:100-114.

Cooper MI, Hutchins GM, Cohen PS, Helman LJ, Mennie RJ, Israel MA (1990) Human neuroblastoma tumor cell lines correspond to the arrested differentiation of chromaffin adrenal medullary neuroblasts. Cell Growth Differ 1:149-159.

Doupe AJ, Landis SC, Patterson PH (1985a) Environmental influences in the development of neural crest derivatives: glucocorticoids, growth factors, and chromaffin cell plasticity. J Neurosci 5:2119-2142.

Doupe AJ, Patterson PH, Landis SC (1985b) Small intensely fluorescent (SIF) cells in culture: role of glucocorticoids and growth factors in their development and phenotypic interconversions with other neural crest derivatives. J Neurosci 5:2143-2160.

Fowlkes BJ, Schwartz PH, Pardoll DM (1988) Deletion of self-reactive thymocytes occurs at a $\mathrm{CD} 4{ }^{+} \mathrm{CD} 8+$ precursor stage. Nature 334 : $620-623$.

Grainger RM, Gurdon JB (1989) Loss of competence in amphibian induction can take place in single nondividing cells. Proc Natl Acad Sci USA 86:1900-1904.

Gurdon JB (1987) Embryonic induction-molecular prospects. Development 99:285-306.

Gurdon JB (1988) A community effect in animal development. Nature 336:772-774.

Henion PD, Landis SC (1989) Evidence for death of committed neuronal precursors in the developing adrenal gland. Soc Neurosci Abstr 15:884.

Henion PD, Landis SC (1990) Asynchronous appearance and topographic segregation of neuropeptide-containing cells in the developing rat adrenal medulla. J Neurosci 10:2886-2896.

Hoeffler JP, Boockfor RR, Frawley S (1985) Ontogeny of prolactin cells in neonatal rats: initial prolactin secretors also release growth hormone. Endocrinology 117:187-195.

Ingraham HA, Chen R, Mangalam HJ, Elsholtz HP, Flynn SE, Lin CR, Simmons DM, Swanson L, Rosenfeld MG (1988) A tissue-specific transcription factor containing a homeodomain specifies a pituitary phenotype. Cell 55:519-529.

Lempinen M (1964) Extra-adrenal chromaffin tissue of the rat and the effect of cortical hormones on it. Acta Physiol Scand [Suppl] 231:1-9. Le Douarin NM (1982) The neural crest. Cambridge: Cambridge UP. Leonard DGB, Ziff EB, Greene LA (1987) Identification and characterization of mRNAs regulated by nerve growth factor in PC12 cells. Mol Cell Biol 7:3156-3157.

Mirsky R (1982) The use of antibodies to define and study major cell types in the central and peripheral nervous system. In: Neuroimmunology (Brockes JP, ed), pp 141-181. New York: Plenum.

Reichardt LF (1984) Immunological approaches to the nervous system. Science 225:1294-1299.

Seidl K, Unsicker K (1989a) Survival and neuritic growth of sympathoadrenal (chromaffin) precursor cells in vitro. Int J Dev Neurosci 7:465-473.

Seidl K, Unsicker K (1989b) The determination of the adrenal medullary cell fate during embryogenesis. Dev Biol 136:481-490.

Stein R, Orit S, Anderson DJ (1988a) The induction of a neuralspecific gene, SCG10, by nerve growth factor in $\mathrm{PC} 12$ cells is transcriptional, protein synthesis dependent, and glucocorticoid inhibitable. Dev Biol 127:316-325.

Stein R, Mori N, Matthews K, Lo L-C, Anderson DJ (1988b) The NGF-inducible SCG10 mRNA encodes a novel membrane-bound protein present in growth cones and abundant in developing neurons. Neuron 1:463-476.

Stemple DL, Mahanthappa NK, Anderson DJ (1988) Basic FGF induces ncuronal differentiation, cell division, and NGF dependence in chromaffin cells: a sequence of events in sympathetic development. Neuron 1:517-525.

Teitelman G, Joh TH, Park D, Brodsky M, New M, Reis DJ (1982) 
Expression of the adrenergic phenotype in cultured fetal adrenal medullary cells: role of intrinsic and extrinsic factors. Dev Biol 80:450459.

Unsicker K, Drisch B, Otten J, Thoenen H (1978) Nerve growth factor-induced fiber outgrowth from isolated rat adrenal chromaffin cells: impairment by glucocorticoids. Proc Natl Acad Sci USA 75: 3498-3502.

Vogel KS, Weston JA (1990) The sympathoadrenal lineage in avian embryos. I. Adrenal chromaffin cells lose neuronal traits during embryogenesis. Dev Biol 139:1-12. 